\title{
Is there really no link between international trade and wage differentials?
}

Lorenzo Corsini

Department of Economics, University of Pisa, Via C. Ridolfi, 10, 56124 Pisa, Italy.

E-mail: Icorsini@ec.unipi.it

\begin{abstract}
This paper investigates empirically the relationship between international trade (in particular with non-OECD countries) and wage differentials of workers with different skills. We examine years from 1996 and 2005 in several countries and, whereas past studies (conducted on previous years) had not detected any relevant relationship, we find a clean cut positive effect of imports from non-OECD countries on differentials. In addition, we find evidence that technological change is having a polarization effect on wages.
\end{abstract}

\section{Introduction}

There is an ongoing debate on whether international trade in general and imports from non-industrial countries in particular, is affecting the within-country wage differentials between skilled and unskilled workers. This is particularly important given the remarkable increase in international trade that we are observing in recent years.

Standard economic theory predicts that competition from non-industrial or developing countries should increase wage differentials between skilled and unskilled workers. This descends from the StolperSamuelson theorem: the increasing competition from less developed countries reduces the price of low skill intensive goods and generates a fall in the price of the factor used in their production process, unskilled labour in this case. Then, as a consequence of the fall in prices, wage differentials should increase.

While this theoretical result appears straightforward, empirical studies have found little evidence that international trade is widening wage differentials. Among the most influential, Krugman (1995) and Machin and Van Reenen (1998) find that trade has almost no role in determining wages. In a survey on this subject, Machin and Van Reenen (2007) conclude that there is little support for a trade based explanation for the 
widening of wage differentials. More recently, two influential studies further fuelled the discussion. Lawrence (2008) confirms the feeble link between trade and wage inequalities, stressing how imports, even from non-industrial countries, often involve technological advanced goods. On the contrary, Krugman (2008) overturns the previous conclusions: according to him, past analyses focused on years when the north-south trade involved mostly Hong Kong, Singapore, South Korea and Taiwan whereas it now involves mostly Brazil, China, India and Mexico: these latter countries have an even lower average wage than the former and thus, international trade produces now an even fiercer competition in low skill intensive sectors.

Our study contributes to this discussion, investigating empirically the relationship between international trade and wage differentials of workers with different degree of skills in several industrial countries. We improve previous analyses in three ways: (i) using more recent data covering year from 1996-2005, capturing thus the shift in international trade that Krugman (2008) suggested; (ii) breaking down workers into three categories of skills (low, medium and high) thus capturing different dimensions of skills; and (iii) using a measure of trade that only consider non-fuel imports from non-OECD countries. Our results show that, in the period of analysis, there is a clear positive effect of imports from non-OECD countries on wage differentials.

Clearly, other factors affect wage differentials. The most obvious is the relative supply of a given category of labour. In addition, technological progress may be skill biased and increases wage differentials (see Katz and Murphy 1992 and Acemoglu 2001). Recent studies (Autor et al. 2003, Manning 2004, Spitz-Oener 2006), also suggest that technological progress actually favours non-routine jobs in the high skill sector but also in the low skill sector, whereas it is detrimental to routine jobs in the medium skill sector. Finally, labour market institutions may also be important to determine differentials (see Koeniger et al. 2007 and Corsini 2012). While we do not focus on these aspects, we include them in our analysis.

The paper proceeds as follows: Section II describes the data and our empirical methodology, Section III presents the results of our analysis and Section IV concludes. 


\section{Data Description and Empirical Methodology}

Our analysis covers years from 1996 to 2005 for a group of European countries (Austria, Belgium, Czech Republic, Denmark, Finland, Germany, Hungary, Netherland, Spain and United Kingdom) plus Japan and United States. The choice of the countries is strictly dictated by the availability of data.

The dataset we use is EU-KLEMS, 2007 release, which contains data on average wages and total hours worked, broken down for three categories of workers: low, medium and high skilled. The distinction is made on the base of educational attainment of individuals; for a full description of the categories see Timmer et al. (2007). From this data we compute wage differentials between workers with different skills (the wage ratio between high and low skilled, high and medium and medium and low) and the relative supply (the ratio of aggregate total hours between workers of different skills). We only use data for male of age from 30 to 49: this allows us to get rid of gender and age compositional issues that could affect wage differentials. In all, we obtain three wage differentials and three relative supplies.

Data on international trade comes from the OECD International Trade by Commodity Statistics. We compute the value of commodities imported from non-OECD countries net of the imports in fuels and ores, measured as a share of GDP: we call this variable "adjusted imports". Given that we are investigating on whether the competition from goods produced in developing countries affect wages, we believe this to be the proper variable to be used in our analysis. In Fig. 1 we depict the values of this variable during the first and the last year. The figure highlights how imports increased largely in all countries (though in the UK and USA the increase was milder). However, the size is rather small compared to overall economy, being usually around $4 \%$ of GDP and only in a few cases reaching $10 \%$. 


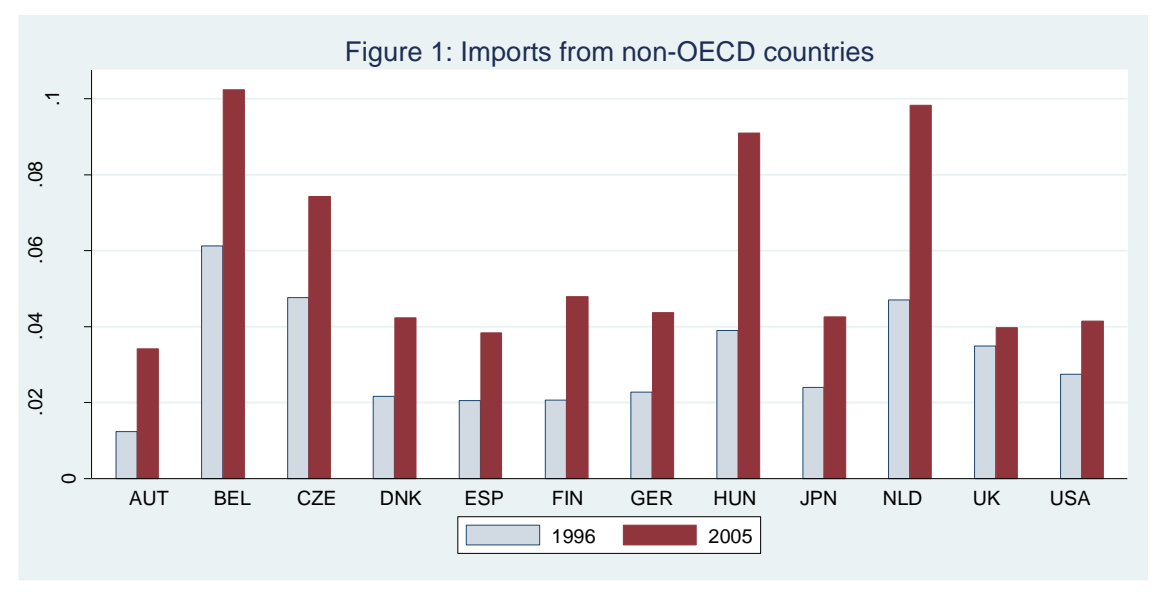

Following previous literature (for example Machin and Van Reenen 1998 and Corsini 2012), we use Research and Development (RD) expenditures over GDP as a proxy for technological change and we also include minimum wages (measured as a share of median wage): data for both variables are taken from the EUROSTAT database. The use of RD expenditures as a proxy of technological progress follows a long line of research: for example, Griliches, Hall, and Pakes (1991) have highlighted how the number of innovations and patents are strictly correlated with RD expenditure and thus the latter is a good measure of the pace of technological process. As for the inclusion of minimum wages, it should capture the fact that the existence of a lower threshold for wages should increase lower skilled income only and thus, decrease the differentials

Given these variables of interests, we want to estimate how wage differentials between workers of different skill are affected by trade from non-industrial countries, controlling for relative supply of workers, technological progress and minimum wages. The equation we wish to estimate is:

1) $W D_{i, t}=c_{i}+d_{t}+\beta_{1} R S_{i, t}+\beta_{2} I M P_{i, t}+\beta_{3} T E C H_{i, t}+\beta_{4} M W_{i, t}+\varepsilon_{i, t}$

where $W D_{i, t}$ are wage differentials ( $i$ and $t$ are country and time index, respectively), $c_{i}$ is the countryspecific constant, $d_{t}$ is a year dummy, $R S$ is relative supply, IMP represents adjusted imports, TECH is technology change (RD as a share of GDP) and $M W$ minimum wages. All the variables are measured in logs. In total we have three series of differentials: high over low skilled (HL), high over medium (HM) and medium over low (ML). Accordingly, we have three series of relative supplies. 
We estimate Equation (1) separately for the three differentials using fixed effect (FE) regressions. This approach is quite common in the analyses on wage differentials (for example, Machin and Van Reenen 1998, Kroeninger et al 2007, Corsini 2012) and it implies a demeaning of all the variables so that country specific constants and year dummies disappear and information on these effects are lost. However, information on the effect of time might be interesting and thus, preliminarily, we only demean with respect to the country clusters, maintaining the year dummy structure. This procedure allows us to analyse the time effect but it has the drawback of having a large number of explanatory variables. From the estimation of this preliminary regression we test whether the time dummies coefficients are statistically different in the different years and we found out that dummies for the years 1996-1998 are not statistically different and the same is true for dummies for 1999-2006. This is true for all the three wage differentials we are considering. Therefore we reformulate the initial regression to include a time dummy for the years 1996$1998\left(D 1_{t}\right)$ and another for the years 1999-2006 $\left(D 2_{t}\right)$ :

2) $W D_{i, t}=c_{i}+D 1_{t}+D 2_{t}+\beta_{1} R S_{i, t}+\beta_{2} I M P_{i, t}+\beta_{3} T E C H_{i, t}+\beta_{4} M W_{i, t}+\varepsilon_{i, t}$.

We estimate the parameters with Prais-Winstein FE regression assuming panel-correlated standard errors, that is, we allow for a non-identical variance-covariance matrix of errors with heteroskedasticity and panelspecific autocorrelation (our results are thus robust to heteroskedasticity and autocorrelation). We only demean with respect of the country clusters so that the two time dummies remain in the actual estimation.

A possible limitation of this specification is that, within a trade model, imports, employment and wage differentials may be simultaneously determined implying a simultaneity issue in the estimation. To check for robustness for this issue we also use another specification where all the independent variables are oneyear lagged: this should overcome the problem of simultaneity.

Other specifications were tried to test the robustness of our results. In particular, though we do not report the results for reason of space, we also estimated Equation (2): (i) using feasible general least square, (ii) using Prais-Winstein regression with cross-correlated errors, (iii) using differentials of workers of all ages 
and genders, inserting workforce composition as independent variables. In all cases, the results were qualitatively similar.

\section{Results}

We present in Table 1 the results of the estimation of Equation (2) for the three wage differentials. The results show that imports from non-OECD countries have a significant role in the determination of wage differentials and we can infer that competitions from these countries ${ }^{1}$ is pushing downward the wages of workers with lower skills.

The time component is relevant in that the coefficient for the time dummy for the years 1996-1998 is (statistically) smaller than the one for the years 1999-2008. This is true for all the three differentials: apparently, in the second period, we observe an increase in the overall inequalities of wage. In any case, the effect of import is significantly positive even when we take into account this time-driven increase of inequality.

We also find that technological change has a positive effect on the $\mathrm{HL}$ differentials (but with borderline significance), a strong positive effect on the HM differentials and a clean-cut negative effect on the ML differentials. These results suggest that technological progress is inducing polarization in wages, with medium skilled workers being penalized by it, low skilled faring relatively better and high skilled having the greatest advantage. The rest of variables do not appear to be significant: the coefficient of relative supply is extremely small while minimum wages have the expected sign but are not significant.

The results remain qualitatively the same when we use lagged variables (see Table 1) so that estimation appears to be robust to simultaneity. Clearly we are not considering other form of endogeneity so that it would be interesting to develop further research in this direction.

\footnotetext{
${ }^{1}$ To further check the robustness of our result we tried to run the regression using total imports from non-OECD countries: while this latter variable had still a positive effect on wage differentials, its magnitude was smaller. Finally, we tried to include both fuel/ores imports and non-fuel/ore imports as distinct variables: the former was not significant, implying that non-fuel imports is the variable truly affecting differentials.
} 
Finally, we try to assess to which extent trade from non-OECD countries is relevant in explaining the overall wage differentials changes between 1996 and 2005. To do this, we compute in Table 2 the estimated change on wage differentials produced by the observed variation in non-OECD imports: this is given by the product between the observed change in imports and the estimated coefficient ${ }^{2}$ of imports (using the coefficients from Table 1 for the non-lagged variables). Comparing the estimated effect of imports on differentials with observed change on differentials, we can assess how important imports from non-OECD countries have been in the evolution of differentials. Our findings (Table 2) show that the share of increase in differentials due to the imports from non-OECD countries is quite variable across countries and, in most cases, large. In a few countries the share is not particularly large (though still relevant) with United States the most evident case (being roughly $10 \%, 22 \%$ and $9 \%$ for the different categories). However, this is due to the relative small increase in the imports rather than to a weak link between trade and differentials. Given that most studies on these aspects were based on evidence from United States, we believe this to be one of the reasons why the role of trade has been underrated in past analyses.

\section{Conclusions}

We find relevant evidence that imports from non-OECD countries affect positively wage differentials between workers with different skills. While this relationship appears clean-cut, the dimension of imports from these countries is still moderate and therefore, especially in UK and US, the role of trade in the determination of differentials is not always large. However, given the rise in international trade that we are currently observing, we believe that international trade is going to be one of the driving forces behind wage inequalities.

\footnotetext{
${ }^{2}$ In fact, we estimated equation 2 using logs, so that coefficients from table 1 can be considered elasticities.
} 
Table 1: Fixed effect regressions for wage differentials

\begin{tabular}{|c|c|c|c|c|c|c|}
\hline & \multicolumn{2}{|c|}{ (1) } & \multicolumn{2}{|c|}{ (2) } & \multicolumn{2}{|c|}{ (3) } \\
\hline & $\begin{array}{c}\text { HL Wage } \\
\text { Differentials }\end{array}$ & $\begin{array}{c}\text { HL Wage } \\
\text { Differentials } \\
\text { (lagged variables) }\end{array}$ & $\begin{array}{c}\text { HM Wage } \\
\text { Differentials }\end{array}$ & $\begin{array}{c}\text { HM Wage } \\
\text { Differentials } \\
\text { (lagged variables) }\end{array}$ & $\begin{array}{c}\text { ML Wage } \\
\text { Differentials }\end{array}$ & $\begin{array}{c}\text { ML Wage } \\
\text { Differentials } \\
\text { (lagged variables) }\end{array}$ \\
\hline Relative Supply & $\begin{array}{r}-0.0176 \\
(0.0429)\end{array}$ & $\begin{array}{c}-0.0231 \\
(0.0442)\end{array}$ & $\begin{array}{l}-0.161 \\
(0.1000)\end{array}$ & $\begin{array}{c}-0.194^{*} \\
(0.108)\end{array}$ & $\begin{array}{c}0.00788 \\
(0.0149)\end{array}$ & $\begin{array}{l}0.0094 \\
(.01459)\end{array}$ \\
\hline Adjusted Imports & $\begin{array}{c}0.0666^{* * *} \\
(0.0219)\end{array}$ & $\begin{array}{c}0.0558^{* *} \\
(0.0256)\end{array}$ & $\begin{array}{c}0.0528 * * * \\
(0.0191)\end{array}$ & $\begin{array}{c}0.0463^{* *} \\
(0.0228)\end{array}$ & $\begin{array}{c}0.0282^{* * *} \\
(0.0102)\end{array}$ & $\begin{array}{c}0.0215^{* *} \\
(.0102)\end{array}$ \\
\hline Technological Change & $\begin{array}{l}0.0887 \\
(0.0662)\end{array}$ & $\begin{array}{l}0.0893 \\
(0.0778)\end{array}$ & $\begin{array}{c}0.1170 * * \\
(0.0504)\end{array}$ & $\begin{array}{c}0.1500 * * \\
(0.0627)\end{array}$ & $\begin{array}{c}-0.0859 * * * \\
(0.0193)\end{array}$ & $\begin{array}{c}-0.0823 * * * \\
(.0232)\end{array}$ \\
\hline Minimum Wage & $\begin{array}{c}-0.1090 \\
(0.169)\end{array}$ & $\begin{array}{c}-0.0945 \\
(0.207)\end{array}$ & $\begin{array}{c}-0.0711 \\
(0.148)\end{array}$ & $\begin{array}{c}-0.0216 \\
(0.151)\end{array}$ & $\begin{array}{c}-0.0396 \\
(0.0303)\end{array}$ & $\begin{array}{c}-0.0164 \\
(.0312)\end{array}$ \\
\hline Years 1996-1998 & $\begin{array}{c}1.3732 * * * \\
(0.285)\end{array}$ & $\begin{array}{c}1.3291 * * * \\
(0.353)\end{array}$ & $\begin{array}{c}0.9394 * * * \\
(0.197)\end{array}$ & $\begin{array}{c}0.9897 * * * \\
(0.230)\end{array}$ & $\begin{array}{l}0.0161 \\
(0.0735)\end{array}$ & $\begin{array}{c}-0.0007 \\
(.0927)\end{array}$ \\
\hline Years 1999-2005 & $\begin{array}{c}1.3950 * * * \\
(0.284)\end{array}$ & $\begin{array}{c}1.3490 * * * \\
(0.347)\end{array}$ & $\begin{array}{c}0.9643^{* * *} \\
(0.191)\end{array}$ & $\begin{array}{c}1.0102 * * * \\
(0.222)\end{array}$ & $\begin{array}{l}0.0291 \\
(0.0720)\end{array}$ & $\begin{array}{l}0.0106 \\
(.0913)\end{array}$ \\
\hline $\begin{array}{l}\text { Chi-squared test on the } \\
\text { equality of year dummies } \\
\text { (p-value) }\end{array}$ & $\begin{array}{l}4.63 * * \\
(0.031)\end{array}$ & $\begin{array}{c}2.73^{*} \\
(0.098)\end{array}$ & $\begin{array}{l}7.18^{* * *} \\
(0.0074)\end{array}$ & $\begin{array}{c}2.84^{*} \\
(0.092)\end{array}$ & $\begin{array}{l}7.71^{* * *} \\
(0.0055)\end{array}$ & $\begin{array}{c}6.42^{* *} \\
(0.0113)\end{array}$ \\
\hline $\begin{array}{l}\text { Observations } \\
R^{2}\end{array}$ & $\begin{array}{c}120 \\
0.991\end{array}$ & $\begin{array}{c}108 \\
0.991\end{array}$ & $\begin{array}{c}120 \\
0.987\end{array}$ & $\begin{array}{c}108 \\
0.987\end{array}$ & $\begin{array}{c}120 \\
0.995\end{array}$ & $\begin{array}{c}108 \\
0.993\end{array}$ \\
\hline
\end{tabular}

Table 2: The effect of change in imports on the wage differentials (1996-2005)

\begin{tabular}{|c|c|c|c|c|c|c|c|c|c|c|}
\hline & \multirow[b]{2}{*}{$\begin{array}{c}\text { Observed } \\
\text { change in } \\
\text { imports }\end{array}$} & \multicolumn{3}{|c|}{ HL Wage Differentials } & \multicolumn{3}{|c|}{ HM Wage Differentials } & \multicolumn{3}{|c|}{ ML Wage Differentials } \\
\hline & & $\begin{array}{c}\text { Observed } \\
\text { change in } \\
\text { differentials }\end{array}$ & $\begin{array}{l}\text { Estimated } \\
\text { change due } \\
\text { to imports }\end{array}$ & $\begin{array}{l}\% \text { of change } \\
\text { due to } \\
\text { imports }\end{array}$ & $\begin{array}{c}\text { Observed } \\
\text { change in } \\
\text { differentials }\end{array}$ & $\begin{array}{l}\text { Estimated } \\
\text { change due } \\
\text { to imports }\end{array}$ & $\begin{array}{c}\% \text { of change } \\
\text { due to } \\
\text { imports }\end{array}$ & $\begin{array}{c}\text { Observed } \\
\text { change in } \\
\text { differentials }\end{array}$ & $\begin{array}{l}\text { Estimated } \\
\text { change due } \\
\text { to imports }\end{array}$ & $\begin{array}{c}\% \text { of change } \\
\text { due to } \\
\text { imports }\end{array}$ \\
\hline Austria & 0.022 & -0.041 & 0.128 & Neg. & -0.043 & 0.079 & Neg. & 0.010 & 0.037 & 3.605 \\
\hline Belgium & 0.041 & 0.240 & 0.065 & 0.269 & 0.115 & 0.042 & 0.360 & 0.061 & 0.018 & 0.295 \\
\hline Czech Republic & 0.027 & 0.249 & 0.087 & 0.351 & 0.183 & 0.051 & 0.280 & -0.001 & 0.017 & Neg. \\
\hline Denmark & 0.021 & 0.177 & 0.078 & 0.441 & 0.054 & 0.051 & 0.949 & 0.076 & 0.023 & 0.302 \\
\hline Spain & 0.018 & 0.157 & 0.094 & 0.596 & 0.138 & 0.052 & 0.377 & -0.023 & 0.025 & Neg. \\
\hline Finland & 0.027 & 0.077 & 0.093 & 1.212 & 0.038 & 0.068 & 1.806 & 0.024 & 0.026 & 1.098 \\
\hline Germany & 0.021 & 0.128 & 0.093 & 0.729 & 0.173 & 0.056 & 0.321 & -0.058 & 0.025 & Neg. \\
\hline Hungary & 0.052 & 0.669 & 0.181 & 0.270 & 0.620 & 0.112 & 0.181 & -0.039 & 0.031 & Neg. \\
\hline Japan & 0.019 & 0.158 & 0.065 & 0.416 & 0.051 & 0.044 & 0.859 & 0.065 & 0.019 & 0.293 \\
\hline Netherland & 0.056 & 0.289 & 0.104 & 0.360 & 0.147 & 0.057 & 0.387 & 0.049 & 0.030 & 0.620 \\
\hline United Kingdom & 0.005 & 0.148 & 0.02 & 0.131 & 0.086 & 0.011 & 0.123 & 0.014 & 0.005 & 0.371 \\
\hline United States & 0.014 & 0.148 & 0.068 & 0.089 & 0.200 & 0.037 & 0.187 & 0.253 & 0.017 & 0.066 \\
\hline
\end{tabular}

Changes are calculated as the difference between the 2005 and 1996
due to the increase of imports. Those cases are recorded with "Neg.". 
Acemoglu, D. (1998) Why Do New Technologies Complement Skills? Directed Technical Change and Wage Inequality, Quarterly Journal of Economics, 113, 1055-89.

Autor, D., Levy, F., and Murnane, R. (2003) The Skill Content of Recent Technological Change: An Empirical Exploration. The Quarterly Journal of Economics, 118, 1279-1333.

Corsini, L., 2012. Institutions, Technological Change and Wage Differentials Between Skilled and Unskilled Workers: Theory and Evidence from Europe. Research in Labor Economics, forthcoming.

Griliches, Z., Hall, B. and Pakes, A. (1991) R\&D, Patents and Market Value Revisited: Is There a Second (Technological Opportunity) Factor? Economics of Innovation and New Technology, 1, 183-202.

Katz, L. F. and Murphy, K. M. (1992) Changes in Relative Wages, 1963-1987: Supply and Demand Factors, Quarterly Journal of Economics, 107, 35-78.

Koeniger, W., Leonardi, M., and Nunziata, L. (2007) Labor Market Institutions and Wage Inequality, Industrial and Labor Relations Review, 60, 340-356.

Krugman, P. R. (1995) Growing World Trade: Causes and Consequences, Brookings Papers on Economic Activity, 2005, 327-77.

Krugman, P. R. (2008) Trade and Wages, Reconsidered, Brookings Papers on Economic Activity, Spring 2008, 103-154.

Lawrence, R. Z. (2008) Blue-Collar Blues: Is Trade to Blame for Rising US Income Inequality? Washington: Peterson Institute for International Economics.

Machin, S. and Van Reenen, J. (1998) Technology and Changes in Skill Structure: Evidence from Seven OECD Countries, The Quarterly Journal of Economics, 113, 1215-1244.

Machin, S. and Van Reenen, J. (2008) Changes in Wage Inequality. Durlauf, S.N, and Blume, Special Paper No. 18, Centre for Economic Performance, London School of Economics.

Manning, A. (2004) We Can Work It Out: the Impact of Technological Change on the Demand for Low-Skill Workers, Scottish Journal of Political Economy, 51, 581-608.

Spitz-Oener, A., 2006. Technical Change, Job Tasks, and Rising Educational Demands: Looking Outside the Wage Structure, Journal of Labor Economics, 24, 235-270.

Timmer, M., Ton van Moergastel, Stuivenwold, E., Ypma, G., O’Mahony, M. and Kangasniemi, M. (2007) EU KLEMS Growth and Productivity Accounts, version 1. 